YAK 347.958

DOI https://doi.org/10.32837/chc.v0i36.205

Нестерцова-Собакарь Олександра Володимирівна,

канАиАат юриАичних наук, Аоцент, професор кафеАри цивільно-правових Аисциплін

Аніпропетровського Аержавного університету внутрішніх справ

ORCID https://orcid.org/0000-0003-0712-4076

\title{
РОЗУМІННЯ СУТНОСТІ ТА ЗМІСТУ ПРИНЦИПУ ЗМАГАЛЬНОСТІ ЦИВІЛЬНОГО ПРОЦЕСУ ЗА СУДОВОЮ РЕФОРМОЮ 1864 РОКУ ТА ЦИВІЛЬНИМ ПРОЦЕСУАЛЬНИМ КОДЕКСОМ УРСР 1924 РОКУ
}

Постановка проблеми. Важливою сутнісною характеристикою цивільного процесу є віАповіАні принципи, які, по-перше, володіють безпосереАньою регулюючою властивістю; по-Аруге, виступають мірилом праворозуміння і основою правозастосування; по-третє, безпосереАньо впливаючи на правосвідомість, на суб'єктивні уявлення, на формування правових іАей опосередковано сприяють розробці нових нормативно-правових актів; по-четверте, зАійснюють гарантуючу функцію, оскільки покликані забезпечувати реалізацію цілей і завАань цивільного суАочинства.

Саме принципи цивільного процесу склаАають його стрижневу основу та визначають вихіАні засади, відображаючи головні якісні особливості. Без принципів неможливо усвіАомити необхіАність вАосконалення цивільного процесуального законодавства, з'ясувати сутність процесуального права як специфічного соціального регулятора.

Попри те, що спільним Аля вчених $є$ трактування принципів права як основних або вихіАних засаА, у з'ясуванні їх сутності та змісту науковці по-різному конкретизують і визначають це поняття. Особливо проблематичним залишається розуміння сутності та змісту оАного з головних принципів цивільного процесу - змагальності, який вперше було законодавчо окреслено судовою реформою 1864 року та конкретизовано Цивільним процесуальним кодексом УРСР 1924 року.

Стан АосліАЖення теми. Повсякчас принципи цивільного процесу стають преАметом пильної уваги вчених різних історичних періодів, оскільки саме $з$ них починається цивільне провадження, зароджуються новітні піАходи Ао вирішення проблемних питань процесуальної науки.

3 цього приводу слушно наголошує М.П. Курило, що Аля вітчизняної процесуальної Аумки проблематика принципів завжАи була і залишається оАнією 3 центральних у АосліАженнях правосудая у цивільних справах [1, с. 34]. Їм присвячені роботи вчених різних періодів, зокрема: А.Х. Гольмстена, Є.В. Васьковського, І.Є. Енгельмана, К.І. Малишева, €.О. Нефедьєва, Т.М. Яблочкова, Н.А. Гредескула та інші. В період панування радянської влаАи на згадану проблему звертали увагу О.П. Клейнман, В.М. Семенов, С.В. Курильов, Р.Е. Гукасян, В.С. Букіна, Й.М. Резніченко, А.А. Ференс-Сороцкого. В нинішніх умовах АосліАженню сутності, змісту та класифікації принципів цивільного судочинства присвячено роботи В.Ю. Мамницького, М.П. Омельченко, А.В. Анарушко, О.В. Рожнова, О.В. Шутенко, М.М. Ясинок, С.О. Волосенко, Г.П. Тимченко, С.Н. Абрамова, П.П. Гуреєва та інших вчених.

Праці вказаних вчених помітно вплинули на формування концептуального уявлення про вихіАні засаАи цивільного судочинства, проте залишається неАостатньо АосліАженим з'ясування сутності та змісту процесуального принципу змагальності через призму судової реформи 1864 року та положень Цивільного процесуального коАексу УРСР 1924 року. 
Отже, мета статті полягає у необхідності з'ясування сутності та змісту процесуального принципу змагальності через призму судової реформи 1864 року та положень Цивільного процесуального коАексу УРСР 1924 року.

ВикиаА основного матеріалу АосліАЖення з повним обгрунтуванням отриманих наукових результатів. Отже, розгляА принципу змагальності цивільного процесу у світлі його еволюційного розвитку Аозволяє показати і довести: через які причини виник і отримав законодавче визнання названий принцип цивільного процесуального права; піА впливом яких чинників віАбувалося його формування і розвиток; яку мету переслідував законодавець, висуваючи на передній план ті чи інші принципи; яка роль віАводилася принципу змагальності цивільного процесу в різні історичні періоди.

Не зменшуючи ролі римського приватного права на еволюцію віАповіАних процесуальних принципів та у безпосередньому впливі на сучасне цивільно-процесуальне законодавство України, віАправною точкою законодавчого закріплення принципу змагальності в цивільному процесі все ж таки доречно вважати судову реформу 1864 року. Саме цей принцип відображав демократичні засади цивільного судочинства того періоду.

Принципу змагальності відводилося особливе значення в організації цивільного судочинства та піАтримувалося усіма віАомими на той час вченими-процесуалістами. Так, А. Гольмстен вважав, що "змагальні засади цивільного судочинства $є$ принципом законодавчої політики, згіАно з яким права сторін рішуче переважають наА офіційними обов'язками суду" [2, с. 130-131].

Статутом цивільного судочинства в основу принципу змагальності було покладено такі елементи: по-перше, суА порушує проваАження у справі на підставі позову; по-Аруге, суА приймає рішення на основі фактів, Аоказів, преАставлених сторонами; по-третє, суА за власною ініціативою не запитує будь-які докази, що підтверАжують (спростовують) позицію тієї чи іншої сторони [3, c. 197].

Умовою реалізації принципу змагальності виступає процесуальна рівність сторін, оскільки змагатися у відстоюванні своїх прав та інтересів сторони можуть мише в оАнакових правових умовах. I навпаки, принцип процесуальної рівноправності сторін забезпечується змагальною формою судочинства, яка надає їм можливість рівною мірою “змагатись" переА судом [4].
Як слушно зауважував Ю.С. Гамбаров: “... змагальні засади полягають в тому, що встановлення, продовження і припинення процесу ставиться <...> у залежність віА волі сторін, яка обмежується судом лише в ріАкісних і виняткових випадках..." [5, с. 73]. Зокрема, сторонам надавалося право на "словесні змагання". Так, у розділі 6 "Про слухання справи" було передбачено, що словесне змагання сторін відбувається завжАи після АоповіАі справи судАею, як у віАкритому, так і в закритому засіданні (ст. 324, 329 Статуту цивільного судочинства).

За задумом авторів статуту суд як орган влади не був зацікавлений в результаті справи на користь тієї чи іншої сторони, його зацікавленість повинна була проявлятися тільки в оАному - в правильному вирішенні спорів. Зокрема, в коментарі до статті 13 Статуту цивільного судочинства зазначено, що піА змагальністю розуміються Аії, які “...належать до прав і обов'язків обох сторін, а обов'язок суду полягає лише в тому, щоб вивести з преАставлених йому Аоводів та обставин, які саме події повинні вважатися істинними, і застосувати до них точну сияу закону..." [6, с. 27].

Розкриваючи сутність змагальної форми, віАомий на той час вчений-процесуаліст K.I. Малишев писав, що під назвою "змагальні засаАи" "ВіАомий принцип цивільного судочинства, за яким різні дії суду в процесі залежать віА вимог сторін, віА їх ініціативи, і спірні віАносини сторін обговорюються лише по тим фактам, які повіАомлені суду обома сторонами. Ці засади випливають із суті цивільних прав, які складають приватну сферу особи і складаються зазвичай у вільному розпоряАженні власника. СуА як орган публічної влади не зацікавлений у користі тієї чи іншої сторони в цивільному процесі, а зацікавлений тільки в правильному вирішенні спору за тими Ааними, які йому повідомлені. Він не повинен ставати на будь-яку сторону і розшукувати Аокази замість їі самої на шкоду іншій стороні <...> Суд не повинен розшукувати і брати Ао уваги такі факти і докази, які не заявлені йому сторонами" [7, с. 352].

Важливе значення принципу змагальності в цивільному процесі також надавав $€ .0$. НефеАьєв, віАзначаючи, що "суА повинен засновувати своє рішення виключно на доказах, преАставлених сторонами, і ні в якому разі не повинен сам збирати докази" [8, с. 194].

Прямо пов'язував змагальність сторін у процесі 3 принципом рівноправності Є.В. Васьковський, а саму змагальність він пов'язував з тим, 
що у сторін в процесі $€$ протилежні інтереси [9, с. $197-198]$.

На Аумку І.М. Тютрюмова, змагальний поряАок в цивільному судочинстві "цілком випливає із суті цивільних прав, які складають приватну сферу особи, а тому знаходяться в його вільному розпоряАженні..." [10, с. 347].

Переваги такої системи віАносин між сторонами і судом, на Аумку вчених-правознавців, полягали в наступному:

- фактична сторона справи може бути встановлена тим, кому вона знайома, хто знає, які існують докази і де вони знаходяться, а такими особами є позивач і відповідач;

- сторони на відміну віА суду більше зацікавлені в з'ясуванні обставин справи, тому позивач і відповідач прагнуть Ао виграшу процесу, намагаючись відшукати і наАати суду всі фактичні обставини і докази;

- підготовка фактичного матеріалу провоАиться Авома спірними сторонами, кожна з яких підбирає все те, що служить на його користь, причому обиАві сторони можуть користуватися Аопомогою аАвокатів, що веде Ао поділу праці, завжАи приносить кращі плоди, ніж виконання всієї склаАної роботи оАнією особою (суАом);

- змагальність віАкриває простір Аля самодіяльності сторін і спонукає їх Ао прояву особистої ініціативи [11, с. 69-71].

Фундаментальним явищем у розвитку цивільного процесуального законодавства України став Цивільний процесуальний кодекс УРСР 1924 р., яким проголошувалися принципи Аиспозитивності, рівності сторін переА судом і законом, рівноправності сторін у процесі, активності суду, що розглядав справу, змагальності, гласності, національної мови судочинства, усності, безпосереАності, безперервності тощо.

Попри проголошене розмаїття принципів цивільного судочинства того періоду, розуміння їх сутності та змісту, а також елементарних основ Аотримання $€$ неоднозначним. Аеякі вчені стверАжували, що він закріпив інквізиційну модель цивільного процесу, в якому надається значна роль судАі і державному прокурору і в якому превалює державний інтерес на противагу приватним інтересам сторін. Хоча навряд чи є Аостатньо підстав Аля висновку про чисто інквізиційну модель судового процесу за ЦПК УРСР 1924 р. ОАнак у частині взаємовіАносин сторін і суду кодекс Аійсно закріплював піАвищену роль суду і прокурора в цивільному суАочинстві.
Порівняно зі Статутом 1864 р. кодексом Аійсно було обмежено Аиспозитивність цивільного процесу та його змагальний характер, оскільки метою цивільного процесу згіАно зі ст. 5 було з'ясування Аійсних прав і взаємовіАносин його учасників. Тому завдання суду піА час вирішення спору про право цивільне полягало в з'ясуванні не формальної, а матеріальної правди. 3 цією метою статті 5, 118 та інші ЦПК УРСР 1924 року на суд поклаАали обов'язок не обмежуватися тільки представменими сторонами доказами.

Цивільний процесуальний кодекс УРСР 1924 р. хоча формально й закріпив Аиспозитивність, але по суті її віАкиАав. ВіАповіАно Ао ст. 2 ЦПК 1924 р. суд розпочинав розгляА справи не інакше, як за заявою зацікавленої сторони, але з метою захисту інтересів держави або трудящих мас прокурору надавалося право як починати справу, так і вступати до неї в будь-якій її стадії. Аалі, за тією ж статтею, прийняття віАмови сторони віА належних їй прав та їх судового захисту належало не безумовному і вільному розсуду сторін, а залежало віА суду. ПіА час вирішення питання про прийняття або неприйняття цієї віАмови суд вирішував, якою мірою така відмова сторони віА належних їй прав не пов'язана 3 експлуатацією економічно більш слабкої Аругої сторони економічно більш сильною, чи не виникає за такої віАмови обходу закону порушення інтересів держави і трудящих мас.

Нарешті, за ст. 179 ЦПК УРСР 1924 року суАу належало право вийти за межі заявлених позивачем вимог, якщо розмір цих вимог не заснований на раніше укладеній угоді сторін або на приписах закону.

Принцип змагальності полягає в тому, що відшукання Аоказів у справі лежить винятково на тяжущіхся, а суд відіграє пасивну роль, будучи мише посередником між сторонами. 3 наведеної вище ст. 5 ЦПК ясно, що принцип змагальності в ЦПК не проводився в чистому вигляАі, оскілки самоАіяльності суду була відведена Ауже велика роль. ЗгіАно зі ст. 118 ЦПК суА міг запропонувати сторонам подати Аодаткові докази, якщо представлені Аокази, на Аумку суду, недостатні. Суд за ст. 121 ЦПК також міг зАійснювати необхідні перевірочні дії за власною ініціативою. 3 цього приводу Верховний Суд РРФСР в ухвалі у справі № 314331924 р. роз'яснив, що “раАянський суА повинен завжАи пам'ятати, що процес по ЦПК - не колишній, чисто змагальний процес, і повинен широко застосовувати ст. 5 ЦПК, не зупиняючись піА час вирішення справи на формальних моментах, а всіляко з'ясовуючи справжні взаємовіАносини сторін, ^іквіду- 
ючи позов, по можливості, в межах того ж процесу і усуваючи необхідність Аля ліквідації віАносин у преА'явленні нового позову". В ухвалі справи № 318471924 р. цивільної касаційної колегії Верховного Суду УРСР указується, що "радянському цивільному процесу не притаманний принцип змагальності, що застосовувався в Аореволюційному суді, і навпаки, закон (ст. 5 ЦПК) проводить начало самодіяльності суду".

Наведені вище фрагменти ЦПК УРСР 1924 р. Аозволяють піАкреслити ту особливість моделі цивільного судочинства, суть якої полягає в патерналістсько-етатичному їі обґрунтуванні в цілому та їі фундаментальних принципів зокрема [12, с. 13-19].

Отже, принцип змагальності цивільного процесу, знаходячи прояв в різних історичних періодах розвитку цивільного процесуального законодавства, являє собою склалне і багатогранне явище, покриваючи собою весь цивільний процес та визначаючи його систему. Звісно ж, розкриття сутності та змісту Ааного принципу в нормах Статуту цивімьного судочинства 1864 року відповідає ліберальній змагальній моделі цивільного суАочинства, тоАі як положення ЦПК УРСР 1924 р., успалкувавши все краще, що було в попередньому процесуальному законодавстві, насправді принцип змагальності сторін повною мірою реалізувати не змогли.

Висновки з АосліАження та перспективи подальших розвідок у цьому напрямі. Таким чином, у різні історичні періоди вітчизняне судочинство будувалося на основі змагальної або слідчої форми, а також на основі поєАнання цих форм, з переважанням однієї з них.

Прийняття Статуту цивільного судочинства 1864 року більшою мірою ґрунтувалося на остан- ніх Аосягненнях іноземного процесуального законодавства та стало вагомою віхою на шляху створення якісного, швиАкого та ефективного цивільного процесу, побудованого на принципах змагальності, гласності, усності, рівності сторін, вільної оцінки Аоказів судом та можливості апеляції і касації.

ОАне з головних завдань, яке було покликане вирішити нове цивільне процесуальне законоАавство, полягало в тому, щоб “замість слідчого процесу в цивільних судових справах прийняти процес змагальний". Водночас Аемократичний характер цивільного процесу, побудований на змагальних засадах, суперечив по суті самоАержавній формі правління, якій не відповідала наявність самостійної, відокремленої віА аАміністрації судової влади. Незважаючи на це, цивільно-процесуальне законодавство Аругої половини XIX ст. залишалося Аосить прогресивним і зАебільшого віАповіАало потребам свого часу.

На віАміну віА Статуту цивільного судочинства, Цивільний процесуальний кодекс УРСР 1924 року, з одного боку, успадкував все краще, що було в попереАньому «імперському" законодавстві, а також використав АосвіА судової реформи 1864 року і цивільного процесуального законодавства зарубіжних, переважно європейських, країн, але з іншого боку, тоталітарні принципи радянської влади унеможливили використання змагальності цивільного процесу. Навіть у радянський період, коли принцип змагальності в цивільному процесі сприймався вченими лише в тісному зв'язку з активністю суду піА час Аоказування, Аіяльність сторін щодо Аоведення обставин, на які вони посилаються як на підставу своїх вимог або заперечень, сприймалася як процесуальний обов'язок.

\section{NITEPATYPA:}

1. Курило М.П. Принципи цивільного процесу як концептуальна правова категорія. Судова апеляція. 2015. № 4. С. $33-40$

2. Гольмстен, А. Х. Учебник русского гражданского судопроизводства / под ред. и с предисловием М.К. Треушникова и Ю.А. Поповой. Краснодар : Совет. кубань, 2004. 484 с.

3. Тарасов В.Н. Преемственность и традиции принципов русского гражданского процесса. Вестник Нижегородской академии МВД России. 2015. № 2. С. 196-200.

4. Голубєва Н.Ю. Поняття та система принципів цивільного процесуального права. Актуальні проблеми держави $і$ права. 2010. Вип. 53. С. 103-114. URL: http://nbuv.gov.ua/UJRN/apdp_2010_53_17.

5. Гражданский процесс: курс лекций, читанных проф. Ю.С. Гамбаровым. Гражданский процесс: хрестоматия / под ред. М.К. Треушникова. Москва, 2005.

6. Судебные Уставы 20 ноября 1864 г., с изложением рассуждений, на которых они основаны, изданные Государственной Канцелярией. Санкт-Петербург, 1866

7. Малышев К. Курс гражданского судопроизводства. Т. 1. Санкт-Петербург, 1874.

8. Нефедьев Е.А. Учебник русского гражданского судопроизводства / Е. А. Нефедьев [печ. по изд.: Нефедьев Е. А. Учебникъ русскаго гражданскаго судопроизводства. Изд. третье. Москва, 1900]. Краснодар : Совет. Кубань, 2005. 480 с.

9. Васьковский Е.В. Учебник гражданского процесса [Текст] / Е. В. Васьковский [печ. по изд.: Васьковский Е. В. Учебникъ гражданскаго процесса изд. второе. М., 1917]. Краснодар : Совет. Кубань, 2003. 528 с.

10. Тютрюмов И.М. Рецензия на книгу г. Краевского Практические заметки о свойствах состязательного начала в гражданском судопроизводстве. Журнал Министерства Юстиции. Санкт-Петербург, 1897. С. 347. 
11. Хрестоматия по гражданскому процессу. Москва, 1996.

12. Комаров В.В. Цивільне процесуальне законодавство у динаміці розвитку та практиці Верховного Суду України. Харків : Право, 2012. 624 с.

\section{Нестерцова-Собакарь Олександра Володимирівна}

РОЗУМІННЯ СУТНОСТІ ТА ЗМІСТУ ПРИНЦИПУ ЗМАГАИЬНОСТІ ЦИВІЛЬНОГО ПРОЦЕСУ ЗА СУАОВОЮ РЕФОРМОЮ 1864 РОКУ ТА ЦИВІЛЬНИМ ПРОЦЕСУАЛЬНИМ КОАЕКСОМ УРСР 1924 РОКУ

У статті зАійснено ще оАин крок Ао поглиблення знань про зміст та особливості реформи цивільного судочинства 1864 року. Особливу увагу приділено Статуту цивільного судочинства та його впливу на розвиток вітчизняного процесуального законодавства як в імперський, так і радянський періоди. З'ясовано сутність та зміст процесуального принципу змагальності через призму судової реформи 1864 року та положення Цивільного процесуального кодексу УРСР 1924 року.

Киючові слова: статут цивільного судочинства, судова реформа, цивільний процес, кодифікація, судоустрій.

\section{Нестерцова-Собакарь Александра Владимировна ПОНИМАНИЕ СУЩНОСТИ И СОАЕРЖАНИЯ ПРИНЦИПА СОСТЯЗАТЕАЬНОСТИ ГРАЖААНСКОГО ПРОЦЕССА ПО СУАЕБНОЙ РЕФОРМЕ 1864 ГОАА И ГРАЖААНСКОГО ПРОЦЕССУААЬНОГО КОАЕКСА УССР 1924 ГОАА}

В статье предпринята еще одна попытка к углублению знаний о содержании и особенностях реформы гражАанского судопроизводства 1864 года. Особое внимание уделено Уставу гражданского судопроизводства и его влиянию на развитие отечественного процессуального законодательства как в имперский, так и советский периоды. Уточнены сущность и содержание процессуального принципа состязательности через призму судебной реформы 1864 года и положения Гражданского процессуального кодекса УССР 1924 года.

Киючевые слова: устав гражАанского судопроизводства, судебная реформа, гражданский процесс, кодификация, судоустройство.

\section{Nestertsova-Sobakar Oleksandra \\ UNDERSTANDING THE ESSENCE AND CONTENT OF THE PRINCIPLE OF COMPETITIVENESS OF THE CIVIL PROCESS UNDER THE JUDICIAL REFORM OF 1864 AND THE CIVIL PROCEDURE CODE OF THE UKRAINIAN SSR IN 1924}

The article takes another step to deepening the knowledge of the content and features of the civil justice reform of 1864. Particular attention was paid to the Statute of Civil Procedure and its influence on the development of domestic procedural legislation in both the imperial and Soviet periods. It is proved that the adoption of the Statute of Civil Procedure in 1864 is largely based on the latest achievements of foreign procedural law and was a significant milestone in the way of creating a qualitative, fast and efficient civil process based on the principles of competitiveness, transparency, veracity, equality of parties, free evaluation and appeal and cassation opportunities. The essence and content of the procedural principle of competition through the lens of judicial reform in 1864 and the provisions of the Civil Procedure Code of the Ukrainian SSR in 1924 have been clarified.

The importance of the principle of competitiveness of the civil process, which is manifested in different historical periods of the development of civil procedural legislation, was a complex and multifaceted phenomenon, covering the whole civil process and defining its system. In particular, the principle of competitiveness was given special importance in the organization of civil proceedings and was supported by all known procedural scientists at that time.

Adoption of the Statute of Civil Procedure in 1864 for the first time allowed to consolidate the relevant procedural law, but at the same time gave rise to several contradictions, including the fact that the democratic principles of the civil process, enshrined in the judicial reform, faced with the lack of independence and judicial conditions. .

The democratic nature of the civil process, as well as of the entire judicial system based on the reforms of 1864 , contradicted the essence of the autocratic form of government, which was not matched by the existence of an independent, separate from the administration of the judiciary. As a result, counter-reforms have restricted a number of progressive principles of judicial reform, including the elimination of the peace court, replacing it with administrative and judicial institutions.

It emphasized the fundamental differences between the Civil Procedure Code of the Ukrainian SSR of 1924 and the Statute of Civil Procedure, which on the one hand inherited all that was in the previous "imperial" legislation, and used the experience of judicial reform of 1864 and civil procedural legislation of foreign, mainly European countries but on the other, the totalitarian principles of the Soviet power made it impossible to use the competitiveness of the civil process. Even in the Soviet period, when the principle of competitiveness in the civil process was perceived by scientists only in close connection with the activity of the court in evidence, the activities of the parties to prove the circumstances to which they refer as a basis for their claims or objections, were perceived as a procedural obligation.

Key words: civil procedure statute, judicial reform, civil process, codification, judiciary. 